\title{
Mechanics of patronage: Christopher Polhem and the changing regimes of the Swedish state (1680-1750)
}

Jacob Orrje

\section{(2) OpenEdition \\ Journals}

Electronic version

URL: http://journals.openedition.org/artefact/383

DOI: $10.4000 /$ artefact.383

ISSN: 2606-9245

Publisher:

Association Artefact. Techniques histoire et sciences humaines, Presses universitaires du Midi

\section{Printed version}

Date of publication: 1 October 2016

Number of pages: 135-146

ISBN: 978-2-7535-5174-9

ISSN: $2273-0753$

\section{Electronic reference}

Jacob Orrje, « Mechanics of patronage: Christopher Polhem and the changing regimes of the Swedish state (1680-1750) », Artefact [Online], 4 | 2016, Online since 07 July 2017, connection on 19 April 2019. URL : http://journals.openedition.org/artefact/383 ; DOI : 10.4000/artefact.383 


\section{Mechanics of patronage: Christopher Polhem and the changing regimes of the Swedish state (1680-1750)}

Jacob ORRJE*

"Similar to how a crowd of soldiers can accomplish little with their manliness without a sensible captain, the whole lot of craftsmen cannot make anything extraordinary without a good mechanicus. » Christopher Polhem, «Thoughts about mechanics» $(1740)^{* *}$.

\section{Résumé}

Cet essai traite des politiques liées à la technologie pendant la période moderne à partir du mécanicien suédois Christophe Polhem. Durant la monarchie absolue du début du xviII ${ }^{e}$ siècle, Polhem obtient avec succès un patronage royal. Mais sous la monarchie constitutionnelle des années 1720, ses relations royales deviennent problématiques. À partir de Polhem, cet article vise à montrer l'ironie de la manière dont certains mécaniciens, présentés comme de fidèles sujets de l'ordre de la première modernité, ont été considérés comme des agents de changements.

Mots-clefs : absolutisme, époque moderne, mécanique, patronage, Suède.

*. Jacob Orrje is a researcher in the Department of Culture and Aesthetics at Stockholm University. In 2015, he completed the PhD Mechanicus: performing an early modern persona on mechanics in eighteenth-century Sweden as an exercise of virtuous subjects in a hierarchic political order. At the moment, he is commencing a postdoctoral research project on the Swedish congregation in eighteenth-century London as a scientific contact zone.

**. Christopher Polhem, «Tankar om mekaniken », Kungliga vetenskapsakademiens handlingar, 1740, nº 1, p. 193. Unless otherwise stated, all translations of Swedish sourcer are my own. 


\section{Abstract}

This essay approaches the politics of early modern technology through the Swedish mechanical practitioner Christopher Polhem. During the absolute monarchy of early $18^{\text {th }}$ century Sweden, Polhem successfully attained royal patronage. But under the constitutional monarchy of the 1720s, his royal connections became a problem. Through Polhem, this essay aims to show the irony of how mechanical practitioners, who presented themselves as faithful subjects of an early modern order, retrospectively have been interpreted as agents of change.

Keywords: absolutism, early modern, mechanics, patronage, Sweden.

This is an essay about the politics of early modern technology, and more specifically how one mechanical practitioner related to, and was formed into a symbol for, changing political orders. Studies of early modern invention have generally focused either on the English constitutional monarchy or on absolutist France. Here, I shift focus from these states, which have often been presented as the source of modern industrialism, to the poor Northern-European state of Sweden. The Swedish case highlights how expectations changed as political systems replaced each other. Furthermore, by changing focus from states traditionally considered the source of Western industrialism, to Europe's northern periphery, I disentangle early modern mechanics from long narratives of modernity and industrialism. In the nineteenth and twentieth centuries, Europe's technological past was enrolled in liberal ideology and historiography, according to which early modern mechanical practitioners were agents who brought about a modern industrial order $^{1}$. In heroic biographies of the time, men such as James Watt and Gottfried Wilhelm Leibniz came to be interpreted as entrepreneurs and as agents of change operating a public sphere, as opposed to the sphere of the state. These men were presented as champions of modernity, often at odds with the contemporaries, or as visionaries who were ahead of their time ${ }^{2}$. The historiography of the Swedish mechanical practitioner Christopher Polhem (1661-1751) is no different, and it follows a similar logic to these other heroes of invention. ${ }^{3} \mathrm{He}$ was born as Christopher Polhammar, a son of a German merchant who, like many other Germans of the time, had made a new life in the rising Swedish empire. By designing useful machinery, mainly in the expanding Swedish metal production, Polhem made a name for himself both among his contemporaries and among later-day historians. Some of his contemporaries came to call him "the Archimedes of the North » and to historians of the $19^{\text {th }}$ and $20^{\text {th }}$ centuries he was the « father of Swedish technology ${ }^{4}$ ». As with other heroes of invention, his historiography is one of a man who aligned himself with the expectations of his contemporary regime and who then was continuously reinterpreted and used by posterity for a multitude of purposes.

By studying Polhem's relationship to the changing political regimes of his 
time, it is not only possible to separate the early modern mechanical practitioner from this nineteenth-and twentieth-century historiography. Also, a study of the early modern politics that made Polhem's technology possible can show the irony of a historiography of technology where mechanical practitioners, who actively presented themselves as faithful subjects of an early modern order, retrospectively have been reinterpreted as standing in radical opposition to their contemporary political culture 5 . In 1740 Christopher Polhem published his "Thoughts about mechanics " in the transactions of the Royal Swedish Academy of Sciences. His text presented the usefulness of mechanics as well as the merits of the mechanicus: the man who was capable of performing mechanics. For Polhem, who all his life had carried out mechanical work in the service of the Swedish state, the mechanicus was defined by his relationships of superiority and subordination with other sub-

\section{Mechanics of absolutism}

From 1680, when Karl XI declared Sweden an absolute monarchy, symbolical representations of the monarch as the power nexus of the realm, modelled after a French example, became common. The monarch continuously needed to manifest his absolute power, in order to balance socially powerful elites at court and throughout the realm. At court, the king's personal power - expressed through favours and patronage - flowed through chains of subjects at different degrees of closeness to the $\mathrm{king}^{7}$. A jects of the realm. When writing this text, Polhem was 79 years old. He had lived a long life, not only as a maker of mechanical inventions - for use in war, mining and manufactories - but also as a valued part of the Swedish scientific communities of natural philosophers and mathematicians. Over the course of Polhem's long life, Sweden's political structure had changed radically. During the first 57 years of his life, Polhem had been a favoured subject of the Caroline absolutist monarchs Karl XI and Karl XII. In the 1720s, Sweden underwent drastic governmental changes. From having been an absolutist state, not unlike France of l'Ancien regime, it became a constitutional monarchy with a weak king and a strong parliament ${ }^{6}$. At this time, Polhem had struggled to reinvent himself as a part of the new regime. Only by the late 1730s, was he rehabilitated and made into a figurehead of the newly established Royal Swedish Academy of Sciences.

growing number of scholars have shown the importance of personal relationships of patronage for early modern arts and sciences. Such studies have revealed how good relationships with the politically powerful were pivotal to early modern scientists and inventors. Such relationships were as much about presenting the patron and client in a positive light, as they were about the distribution of resources and favours. These relationships shaped patrons and clients alike: the sovereign's symbolic power was 
made in relation to his subjects and a relationship with the absolute king could make or break the fortune of a civil servant, artisan or scholar:

Considering that Polhem lived as a subject of the Caroline monarchs Karl XI and Karl XII up until he was 57 years old, it is unsurprising that he was shaped by the absolutist regime. In an handwritten autobiography from 1733, Polhem described himself as a man from a simple background with a mechanical inclination but who struggled to receive a formal education. He had not started his studies at Uppsala until 1687, when he was 26 years old, after a clergyman had seen his mechanical work and had recommended him for studies there?

The first part of this autobiography is written like an origin story of a man struggling to overcome his simple background. The climax of this narrative is an episode describing Polhem's work on the astronomical clock of the Uppsala Cathedral. Polhem daimed that he succeeded in repairing the clockwork, which had been broken for over a century, and that he had even improved upon the original design. However, he also noted that " nothing was more annoying, than the fact that I received little help with the heavy work in the church ». Instead, he carried pieces and rods himself, and the students who saw him considered him not one of their peers but « the professors' blacksmith ${ }^{10}$ ». In the narratives of twentieth-century biographers of Polhem, this episode has often been taken as the first sign that Polhem's contemporaries were unable to fully recognise his genius ${ }^{11}$. However, this autobiographical account is hardly a source that can be used as a neutral description of past events. Polhem, like many other European mechanical project makers of the time, was highly conscious of the image of himself that he presented in his published and unpublished texts ${ }^{12}$. When Polhem presented his simple background, and how he was scorned by the other students, this was as much a way for him to distance himself from the average student, as a description of how they distanced themselves from him. By describing how he performed heavy work shunned by students and scholars alike, Polhem could present himself as a practical man, who did not even hesitate public humiliation in order to bring theory and practice together for the usefulness of his sovereign. In his autobiography, Polhem thus clearly aligns himself with the worldly bureaucracy in Stockholm, and against the scholarly world in Uppsala as traditionally formulated $^{13}$.

Moreover, nineteenth- and twentiethcentury biographers have generally overlooked the thick symbolism that permeated Polhem's autobiographical episode about the astronomical clock. In early modern Europe, the power of machines were used as metaphors, analogies and symbols, through which one could understand social forces and abstract entities at play in the world ${ }^{14}$. Mechanics and geometry were part of an authoritarian political order, where products of mechanical work, and the dominion of mechanici over craftsmen and nature alike, became a means of arguing for a centralist vision of society, the rule of God and the absolute monarch ${ }^{15}$. In return, the mechanical conception of political order legitimated certain ways of constructing machines, where ideal 
machines were perceived as autonomous and hierarchical ${ }^{16}$.

In the light of this mechanico-political symbolism, the narrative of Polhem repairing a model of the universe in Uppsala Cathedral become much more than a mere description of mechanical proficiency. The Cathedral of Uppsala was not any building. The absolute monarchy was legitimated by a protestant theocratic ideology, according to which religion and politics were impossible to separate. As the administrative centre of the church and the traditional place where King's were crowned, the Cathedral was the symbolical heart of this ideology, and of Swedish religious and royal power ${ }^{17}$. Despite being a lowly mechanicus, by repairing the clock, and by writing about his accomplishment, Polhem could thus present himself to his contemporaries in a fashion that bore some similarities to the symbolic role of the monarch in an absolutist state. His work positioned him as a guarantor of social order: he was a faithful and useful subject who could repair and improve upon the social machinery that upheld the hierarchies of the realm; he was simultaneously a pious man and submissive subject of his sovereign, and a powerful actor who could restore and maintain the order of the Swedish state.

While a striking example, the fact that the Cathedral was unusual in its explicit symbolical function begs the question of whether Polhem's later work, mostly focused on mining machines, carries any of the same symbolism. How were these, more prosaic, machines made in relation to the absolutist regime? In the 1690s, the Swedish mining administration shifted focus from curious chemical knowledge to useful knowledge based on mathematics, and mechanical practice became an increasingly important part of its work $^{18}$. In his published Short history of the most exquisite mechanical inventions (1729), Polhem wrote of how, after having finished the clock, he was asked by the Bureau of Mines in Stockholm to create a model of an hauling installation. Polhammar proposed a completely mechanical solution, which in principle would carry ore in barrels up to the surface without the need for any workers. The model was well received by mining cameralists in the Bureau. According to Polhem's own account, even the king had observed the model, "with the most gracious delight during 3 hours at the palace ${ }^{19}$ ». Again, we see how according to the mechanical conception of political order, the monarch's interest in the machinery was interpreted as a sign of the machine's usefulness and of Polhem's skill as a mechanicus.

With help from his patron Fabian Wrede (1641-1712), in 1697, Christopher Polhem nurtured his contacts with the king and his cameralists. Wrede was a former president of the Bureau of Mines who had moved on to become the president of the State Office and the Bureau of Accounts) and thus had influence with the monarch. Consequently, Polhem and Wrede convinced Karl XI to establish a Laboratorium mechanicum. In the Laboratorium, Polhem would educate young men in mechanics and other mathematical sciences through practical exercises and with the help of a chamber of mechanical models. During the first decade of the 1700s, Polhem thus became the state's arbiter of mechanical aptitude. The Bureau regularly consulted Polhem 
on mechanical matters and especially when they needed to determine the skill of applicants. Moreover, two mechanical stipends were instated in 1699 to encourage young men to study mechanics for Polhem and it was up to him to decide who received these stipends. The historian Jay Smith has shown how in absolutist France, Louis XIV reaffirmed his power by making the bureaucracy act according to certain principles of merit. ${ }^{20}$ By making Polhem the single authority for the stipends, and by highlighting competence in mechanics in favour of recommendations, Karl XI acted in a very similar way. Through a personal relationship with the king, Polhem was instilled with a power to sidestep the personal modality of service - based on networks of kinship and favours - in the Bureau of Mines. In reality, however, he used this authority to promote his own sons, as well as other young men who were close to him. In the early 1700s, the Bureau's mining mechanics was thus more or less a Polhem family affair ${ }^{21}$.

\section{Becoming the Swedish Daedalus}

Shortly after establishing the Laboratorium mechanicum, Karl XI died in 1697 and his son, Karl XII, became the sovereign of the Swedish realm. After only a few years, an alliance of Denmark-Norway, Saxony, Poland and Russia declared war on Sweden. Thus, in 1700, the Great Northern War started, which lasted until 1721. After some initial success in the field, the fortune of war turned against the Swedish armies and Karl XII ended up retreating to Bender in the Ottoman Empire, where he lived in exile between 17091714. During these years, the king ruled Sweden through sporadic and inefficient letter correspondence: transporting the official letters one way over the whole European continent could take several months. However, the king still took an active interest in the domestic affairs of the Swedish realm ${ }^{22}$.

During the regime of the new king, Polhem maintained and strengthened his position as an arbiter of mechanical competence in the mining administration, partly by cultivating a relationship with Wrede ${ }^{23}$. However, in 1711 Polhem started to seek ways of influencing the monarch that circumvented his patron. There is no source that definitely answers why he side stepped his patron at this time, but one likely reason is that Wrede, and by extension Polhem, had lost the king's favour because of his opposition to the war effort. In October 1711, Polhem's friends in the Collegium Curiosorum, a short-lived scientific society consisting of Uppsala scholars, thus sent a letter of recommendation on his behalf to the king's secretary of state, Casten Feif (1662-1739). The scholars regretted that Polhem's work was suffering due to his lack of funds during the economically difficult war times. Especially, lack of financial support meant that Polhem could only work on mechanical theory and lesser models, and he could not engage in practical work which required more resources. In 
order to unite the theoretical and practical aspects of mechanics, royal support was thus of the essence ${ }^{24}$. A couple of days later, Polhem himself sent Feif a similar letter, in which he offered his skills to the monarch ${ }^{25}$.

Feif was an ideal recipient of these letters. He was in charge of domestic affairs and acted as a mediator between the king and the officials of the bureaus back in Stockholm. In his correspondence with representatives of the state apparatus, he comes across as a man who was shaped by French and German literature on cameralism and policing, and who took an interest in matters of œeconomy (i. e., public economy) and useful knowledge ${ }^{26}$. Feif was thus no passive conduit in the correspondence between Polhem and the king. Quite the opposite: as we will see, he nurtured the king's relationship with Polhem in order to reshape the public image of the king into that of a sovereign informed by the latest œconomical, mathematical and mechanical knowledge.

The ensuing correspondence between Polhem, Feif and the king - that travelled back and forth between the northern and south-eastern borders of the European continent - soon lavished in mutual praises. In his letters to Polhem, Feif described the king as interested in, and somewhat knowledgeable of, mechanics and mathematics. Feif described how the king had " a particular liking of mechanics » and how the king read Polhem's letters with pleasure. He even argued that the king had a certain mechanical skill himself ${ }^{27}$. In his correspondence with third parties, Feif praised Polhem's mechanical skill. For example, in a letter to the president of the chan- cery, Arvid Horn, Polhammar used the royal patronage of Polhem as a symbol for the king's interest in useful arts and sciences in general, and consequently as a proof for these arts' importance for the realm ${ }^{28}$. Likewise, Polhem discussed the king's love for mechanics in his correspondence with Swedish scholars. To Pehr Elvius the elder, the mathematics professor at Uppsala, Polhem told how " Feif writes that His Majesty is very much a libhaber [sic], or a lover of mechanics, and knows fairly much thereof $\mathrm{f}^{29}$ ». Polhem even used the monarch's perceived interest as an argument for young students to start studying mechanics and mathematics.

In this correspondence, it is evident that early modern mechanics, like other arts, carried a political role in the sense that it could be used by the sovereign, or by men such a Feif who acted on behalf of the sovereign, in order to stage the monarch in a specific way. From the mideighteenth century, biographers of Karl XII started to discuss his aptitude for mathematics. The correspondence with Polhem, as well as similar contacts with Emanuel Swedenborg, were routinely used as evidence for the king's knowledge of these sciences. In his biography of Karl XII, the French philosophe Voltaire discussed how "quelques personnes ont voulu faire passer ce Prince pour un bon Mathématicien ». But Voltaire was not convinced: "la preuve que l'on donne de ses connaissances en Mathématique n'est pas bien concluante $^{30} »$. The correspondence between Polhem and Feif thus became a way for both parties to reshape Karl XII into a camerally inclined monarch while also making Polhem into a certain form of faithful subject: a mechanicus. 
As a result of his royal contacts, Polhem was ennobled in December 1716 and given the position as a councillor of the Bureau of Commerce ${ }^{31}$. His new nobility and state position conciliated Polhem's formal social position with the actual position that he had gained from his royal contacts. If our narrative would have ended here, it would have been a classic example of how a successful inventor managed to convince his prince, and through him his contemporaries, of his excellence. History of science is full of these stories: pointing

\section{Regime changes}

On the 30 November 1718, during the siege of the fort Fredrikshald in Norway, Karl XII was killed by a stray bullet that penetrated his head. Following the king's death, the Swedish political system underwent radical changes. In only a handful of years, the strict Swedish autocracy was transformed into a constitutional monarchy. Following the end of the Great Nnorthern War, Sweden had lost many of its territories around the Baltic Sea. Moreover, the realm was now in practice governed by parliament and the king had been reduced to a mere ceremonial function ${ }^{32}$.

For Polhem, this meant that his special position, based on royal patronage, quickly eroded. He was no longer employed in any mechanical projects initiated by the state, he was increasingly side-stepped in matters of awarding stipendiaries in the Bureau of Mines and his manufactory in Stiernsund was no longer exempted from tax. In 1722, Polhem himself commented on his out the successful strategies and tactics used by men in search of funding and credibility. But the relationship between Polhem and Karl XII can teach us another, and perhaps more important, lesson: how the boundary between success and failure is dangerously thin and under constant renegotiation. Not even two years later, Karl XII would become a casualty of war. In the aftermath of the king's death, Polhem's former relationship with the monarch would put a halt to Polhem's mechanical work.

struggles in the constitutional regime. In a number of letters to his friend Erik Benzelius, the librarian of Uppsala University, he complained about the political developments of his time. He asked his friend to " consider what happens in a private household, where the master and the children are put under the guardianship of the servants ». Having been an active part of the old regime, where his mechanics benefitted from the actual and symbolical correspondence between the mechanicus and the absolute monarch, Polhem was convinced that under this regime, where « nothing is considered good that is not supported by the majority ", his mechanical work would be « valued even less ${ }^{33} »$. In his letters, Polhem thus comes across as a man, who had now seen both his symbolical meaning and political networks crumble down and who had not yet found a new place in the constitutional regime.

While at least a portion of Polhem's lack of employment in the early 1720 s 
can be explained by the poor economy of Sweden after its defeat in the Great Northern War, there is also strong indications that Polhem was actually bypassed because of his links to the old regime. For example, mechanical practitioners without the same ties to the former king had much more success in receiving support for their mechanical projects. In contrast to Polhem, in 1722 Anders Gabriel Duhre, a former student of Polhem, presented to parliament a series of works in which he proposed to transform society by founding a Laboratorium mathematico-œconomicum, partly modelled after Polhem's Laboratorium mechanicum. Like Polhem, Duhre had been a part of the mining administration in the early 1700 s, but he had never had the same prominent position in the Bureau, nor had he had the direct royal connections of Polhem. In Duhre's proposed Laboratorium, young men would be made into virtuous citizens through the combined exercise of mathematics and crafts. Whereas Polhem argued against the new political regime in his letters to Benzelius, Duhre's proposal was consciously crafted with the members of the recently empowered parliament in mind. Duhre argued for the usefulness of mechanics and mathematics for nobility, clergymen, peasants, and burghers alike - notably the specific estates according by which the parliament was divided. He also presented reform of agriculture, mining and trade, according to mathematical-œconomical principles, as a quick fix for the struggling Swedish economy. Consequently his proposals were well received in parliament, and parliament granted Duhre favours not unlike those given to Polhem by the former monarch ${ }^{34}$.
When one regime gave way to another, Duhre benefitted from his lack of a relationship with the former monarch. But there are also differences in the mechanical vision presented by the two men. Whereas Polhem's autonomous machinery conformed to a centralist ideal, Duhre's proposed project reflected the contradictory characteristics of the early constitutional monarchy of the 1720s. On the one hand, the power of this new regime was decentralised in ways that had few parallels in other eighteenthcentury European states (comparable only to Great Britain and the Dutch Republic) ${ }^{35}$. On the other hand, the estates of the parliament can be said to have replaced the former absolutist monarch, and to have established " an absolutism of the Diet [parliament] $]^{36}$ ». While its power was decentralised, the new regime was still conceived in theocratic and hierarchical terms.

As pointed out by historian of technology Svante Lindqvist, by the 1720 s men such as Polhem, who used a relationship with the monarch to circumvent the hierarchies of promotion of the state apparatus, became a thing of the past. Instead, mechanical practitioners needed to establish networks in the communities of the state bureaus and in parliament. Duhre's project embodied these ideals almost perfectly: instead of presenting designs for the construction of autonomous machinery, his project proposed the education of a whole new generation of virtuous men, shaped by studies of mathematics and œconomy, who would be trained to participate in the work of the state and who would thus together restore the Swedish state to its former glory. 


\section{Conclusions: reinventing Polhem}

At the turn of the century 1900, when Sweden was undergoing rapid industrialisation, the conservative Swedish historian Samuel Bring published a number of biographies of Karl XII and Christopher Polhem, which presented the two men as national symbols. Whereas Karl XII was staged as a war-hero and symbol of the greatness of the former Swedish empire, Polhem was presented as a visionary who had identified Sweden's potential as an industrial nation before anyone else. During the twentieth century, as Sweden was modernised in both a political and technological sense, Polhem was increasingly disentangled from the absolute monarch. While the image of him as a "Swedish Dædalus » or a « Father of Swedish technology " remained, he was increasingly staged as an historical anomaly, a man ahead of his time. By the late twentieth century, museum exhibitions and popular historians increasingly presented him as an entrepreneur, or a free agent who struggled to change his technologically backward contemporaries ${ }^{37}$.

However, such characterisations depend on very problematic interpretations of historical sources. In his autobiographical accounts, and his letter correspondence, Polhem instead emerges as a man who was struggling to make himself relevant to powerful contemporary audiences. He is thus a prime example of how early modern mechanics was not necessarily an agent of change. Instead, mechanical practitioners could present their work as a means of maintaining the hierarchies of their time, or even to restore a lost greatness of previous eras. In early modern
Sweden, to perform mechanics was to claim an easily identifiable position in a web of asymmetric relationships, ultimately leading up to the sovereign or to the estates of the parliament. Only when he was submitted to contemporary political power, was Polhem trusted to carry out his mechanical work, and only when aligned with contemporary expectations was his work considered useful and hence supported financially. Instead of a man who was too brilliant to be truly understood by his time, Polhem was thus a man who at times was highly successful, at times less so, in convincing relevant contemporary audiences of the political importance of his technology. 


\section{Notes}

1. William J. Ashworth, "The ghost of Rostow: science, culture and the British industrial revolution ", History of science, 2008, $\mathrm{n}^{\circ} 46-3$, p. 249-274; William J. Asнwоrтh, "The British industrial revolution and the ideological revolution: science, neoliberalism and history ", History of science, 2014, n०52-2, p. 182.

2. Christine MACLEOD, "Concepts of invention and the patent controversy in Victorian Britain ", in Robert Fox (dir.), Technological change: methods and rhemes in the history of technology, Amsterdam, Routledge, 1996, p. 137-153; id., Heroes of invention: technology, liberalism and British identity, 1750-1914, Cambridge, Cambridge university press, 2007.

3. Heroic narratives of Polhem can be found in Samuel E. BRING, "Bidrag till Christopher Polhems lefnadsteckning ", in Christopher Polhem: minnesskrift ufgifven av Svenska teknolog-föreningen, Stockholm, 1911; Michael Lindgren and Per Sörвом, Christopher Polhem 1661-1751: « The Swedish Daedalus ", Stockholm, Sveriges tekniska museum, 1985; Michael Lindgren, Christopher Polhems testamente: berättelsen om ingenjören, entreprenören och pedagogen som ville förändra Sverige, Stockholm, Innovationshistoria förlag, 2011.

4. M. Lindgren, "Christopher Polhem ", Dictionary of Swedish national biography, 1995, vol. 29, p. 388 .

5. On the problems associated with the long narratives of histories of science and technology, see Andre WAKEFIELD, "Butterfield's nightmare: the history of science as Disney history ", History and technology, 2014, n 30-3, p. 232-251.

6. For an overview of Swedish political developments at this time, see Michael RoBErTs, The Age of Liberty: Sweden 1719-1772, Cambridge, Cambridge University Press, 1986.

7. On absolutism and the balancing of socially powerful elites, see William BEIK, «The absolutism of Louis XIV as social collaboration ", Past \& Present, $2005, n^{\circ} 188-1$, p. 195-224; on the staging of the absolute monarch, see Jean-Marie Apostolidìs, Le roimachine: spectacle et politique au temps de Louis XIV, Paris, Éditions de minuit, 1981; Peter BURKE, The fabrication of Louis XIV, New Haven, Yale university press, 1992, p. 151-178; Swedish scholars have only recently started to study representations of the absolute monarchs of the $17^{\text {th }}$ century. See for example Mårten SNICKARE, "Shaping the ritual space: Nicodemus Tessin the younger and Swedish royal ceremonies ", in Allan ElLENius (dir.), Baroque dreams: art and vision in Sweden in the era of greatness, Uppsala, Uppsala university, 2003, p. 124-50; Kekke
STADIN, « The masculine image of a great power: representations of Swedish imperial power c. 1630$1690 "$, Scandinavian Journal of History, 2005, n 30-1, p. 61-82.

8. For an in-depth study of patronage of mathematics and natural philosophy in absolutist regimes, see Mario Biagioli, Galileo, courtier: the practice of science in the culture of absolutism, Chicago, University of Chicago press, 1993. On the social and ideological world giving purpose and meaning to technological work in early modern absolutist France, see Ken ALDER, Engineering the revolution: arms and enlightenment in France 1763-1815, Princeton, Princeton university press, 1997.

9. M. Lindgren, «Christopher Polhem », op. cit., p. 388.

10. Christopher PolHeM, «Lefvernesbeskrifning", in Henrik Sandblad (dir.), Christopher Polhems efterlämnade skrifter, Uppsala, Almqvist \& Wiksell, 1954 [1733], vol. 4, p. 387-96

11. See for example S.E. BrING, "Bidrag till...», op. cit., p. 118; M. Lindgren, Christopher Polhems testamente... op. cit., p. 281.

12. The way Polhem presented his services is very similar how his contemporary Liebniz played to " an audience of dukes, courtiers and fiscal officials ", as shown by Andre WAKEFIELD, "Leibniz and the wind machines ", Osiris, 2010, $\mathrm{n}^{\circ} 25-1$, p. 188.

13. For a discussion of how theory of practice can be seen as epistemic virtues of the subjects of the theocratic state of absolutist Sweden, see Jacob ORRJE, Mechanicus: performing an early modern persona, Uppsala, Uppsala university, 2015, chapter 2.

14. Jonathan SAWDAY, Engines of the imagination: renaissance culture and the rise of the machine, London, Routledge, 2007, p. 54.

15. Marc RAEFF, "The well-ordered police state and the development of modernity in seventeenth- and eighteenth-century Europe: an attempt at a comparative approach », The American historical review, 1975, no 80-5, p. 1229-1230; Otto MAYR, Authority, liberty \& automatic machinery in early modern Europe, Baltimore, Johns Hopkins university press, 1986, p. 115-121.

16. O. MAYr, Authority, op. cit., p. 102-103, p. 115121; Simon SCHAFFER, «Enlightened Automata », in William Clark, Jan Golinski et Simon Schaffer (dir.), The sciences in enlightened Europe, Chicago, University of Chicago press, 1999, p. 136.

17. The last king to be crowned in Uppsala was Karl XI. Karl XII moved his coronation to Stockholm, partly by practical reasons, partly as a manifestation of the new centralisation of functions and institutions to the capital, Marrten SNICKARE, Enväldets riter: kungliga fester och ceremonier i gestalt- 
ning av Nicodemus Tessin den yngre, Stockholm, Raster, 1999, p. 145.

18. Hjalmar Fors, The limits of matter. Chemistry, mining, and Enlightenment, Chicago, The university of Chicago press, 2015, p. 74; J. OrRJe, Mechanicus, op. cit., p. 84 .

19. C. Polnem, Kort berättelse om de förnämsta mechaniska inventioner som tid efter annan af Christopher Polhem blifwit påfundne och til publici goda nytta och tienst inrättade, Stockholm, Andreas Biörkmans encka, 1729, p. 11.

20. Jay M. SмIтн, The culture of merit: nobility, royal service, and the making of absolute monarchy in France, 1600-1789, Ann ARBor, University of Michigan press, 1996, p. 264.

21. J. OrRJe, Mechanicus, op. cit., p. 100-102.

22. Åsa KARLsson, Den jämlike undersåten: Karl XII: s förmögenhetsbeskattning 1713, Uppsala, Uppsala university, 1994, p. 32.

23. H. Fors, op. cit., p. 82-83; J. OrRJE, Mechanicus, op. cit., p. 84-85.

24. Letter from Collegium curiosorum to Casten Feif, 1711-10-05, Codex Br. 31, Library of the diocese of Linköping, Sweden.

25. Polhem's letters to Feif, like all other incoming correspondence to Feif during his time in Bender is unfortunately lost. However, in his reply Feif discussed the content of Polhem's letter explicitly and also mentioned the date he Polhem sent it in. See Casten FeIF, "Letter to Christopher Polhammar, 1712-02-09 », Karolinska förbundets årsbok, 1911, p. 238-242.

26. His interests are clearly expressed in his correspondence with the architect Nicodemus Tessin. See C. FEIF, « Letter to Nicodemus Tessin, 171202-30 ", in Gustaf Andersson (dir.), Handlingar ur v. Brinkmanska archivet på Trolle-Ljungby, Örebro, N.M. Lindh, 1859, p. 143-149; C. FeIF, « Letter to Nicodemus Tessin, 1712-11-19 ", in G. ANDERsson (dir.) op. cit., p. 161-65; C. FEIF, « Letter to Nicodemus Tessin, 1713-07-17 », in G. ANDERsson (dir.), op. cit., p. 174-184.

27. C. FeIf, « Letter to Christopher Polhammar, 1712-03-05 ", Karolinska förbundets årsbok, 1911, p. 242-244.

28. C. FeIF, « Letter to Arvid Horn, 1712-03-26 », in Personhistorisk tidskrift, 1921, p. 109-111.

29. C. Polnem, " Letter to Petrus Elvius, 1712-05-31 ", in Christopher Polhems brev, Axel Liljencrantz (dir.), Uppsala, Almqvist \& Wiksell, 1941, p. 87-89.

30. Voltaire, Histoire de Charles XII, roi de Suède, divisée en huit livres, avec l'histoire de l'empire de Russie sous Pierre-le-Grand, en deux parties divisées par chapitres, Genève, Cramer, 1768, p. 382.

31. M. Lindgren, "Christopher Polhem », op. cit.

32. On Sweden of the so-called Age of Liberty, see M. ROBERTS, The Age of Liberty, op. cit.

33. C. Polhem, "Letter to Erik Benzelius, 172208-09 ", in Axel Liljencrantz (dir.), Christopher Polhems brev, Uppsala, Almqvist \& Wiksell, 1941, p. 144-146; C. PolHeM, « Letter to Erik Benzelius, 1722-11-05 », in Ibid., p. 160-163.

34. For a more in-depth discussion of Duhre and his «laboratorium ", see J. ORRJE, Mechanicus, op. cit., p. 158-198.

35. M. RовеRтs, The Age of Liberty, op. cit., p. 217.

36. Ibid., p. 62.

37. See for example the on-going exhibition Teknika museet (the museum of technology) in Stockholm with the signifying name "Christopher Polhem - back to the future ». 